\title{
The Chapter on Appeasement
}

\author{
[Introduction]
}

Next I will proclaim this supreme secret, which has been extolled by Rudra, ${ }^{1}$ which confers great fortune, pacifies great obstacles, causes great appeasement, is auspicious, extinguishes untimely death, wards off all diseases, destroys the enemies' armies, always increases victory ${ }^{2}-$ an army of all deities and seizers, ${ }^{3}$ granting the desired results, the eternal law called the power of complete appeasement. (1-3)

$$
\text { [Maheśvara] }
$$

He who bears the half moon, who has three eyes, who is invested with the sacred thread of a snake, who is four-faced, ${ }^{4}$ four-armed, covered

${ }^{1}$ The compound rudrodgita is attested elsewhere in SkP Revākhanda 93.21, SkP 'Vāyu' Revākhaṇda 4.51 and SkP 'Vāyu' Revākhaṇda 60.8. In all these passages the compound is clearly a tatpuruṣa with an instrumental relation. The same meaning must underlie its use here. The Sivadharma is told to the sages by Nandikeśvara at the request of Sanatkumāra. In the opening verses of the Śivadharmaśāstra (ŚiDhŚ 1.10-11), Nandikeśvara indicates that the original teaching was given by Śiva to Pārvatī, Skanda, the Gaṇas and Nandikeśvara himself. Presumably Nandikeśvara refers to this initial moment of teaching with the reference rudrodgita. Cf. also the analysis of the Sivadharmavivarana (appendix): rudrenotkrșțatvena kathitam 'taught as being supreme by Rudra'.

${ }^{2} \mathrm{P}_{32}^{T}$, and $\mathrm{P}_{72}^{T}$ with variant readings, adds: 'paralyzing the enemy's army, always destroying the enemy'.

3 The author of the Sivadharmavivarana takes this to mean 'an army against all deities and seizers'.

4 Śiva is described here as four-faced, which is a relatively archaic feature of his iconography. For the historical development of the number of heads of Śiva, see Bakker 1997 and Törzsök 2013. Sadāśiva, the central deity of the Śaiva Siddhānta, is considered to be five-headed, but in early literature Śiva is said to be four-headed. 
with white ash, the best, the excellent, bestower of boons, ${ }^{5}$ God of gods, Maheśvara, worshipped in the three worlds, glorious - may he quickly bestow peace on me! (4-5)

\section{[Umā]}

With a body possessed of all limbs, ${ }^{6}$ and slender-waisted, with a very gentle smooth complexion that is both golden and dark, beautiful, furnished with a tilaka on her forehead, bearing the sickle of the moon, ${ }^{7}$ wearing bright clothes, the goddess, adorned with all ornaments, who has a most beautiful feminine form, great abode of beauty and of virtues, pleased simply by devotion, Umā, the goddess, bestower of boons, having arrived in person, with a peaceful form, of immeasurable splendour - may she bestow peace on me, she who is loved by her devotees and fond of devotion! ${ }^{8}(6-9)$

\section{[Kārttikeya]}

With a ruby-coloured lustre, gentle, with a red garland and red unguent, ${ }^{9}$ not a child, yet with the appearance of a child, ${ }^{10}$ six-faced, riding on a peacock, with a face like the full moon, tranquil, with three tufts of hair, furnished with a spear, sprung from the body of the Kṛttikās, Umā, Agni and

5 The sequence vara, varenya, varada is well attested in Purānic literature. It does not appear in the epics.

${ }^{6}$ The choice between sarvāvayavapūrnena and sarvāvayavamukhyena is an arbitrary one.

${ }^{7}$ Like Śiva, Umā is decorated with the sickle of the moon.

${ }^{8}$ The manuscripts are divided between bhaktivatsala and bhaktavatsalā. The phrase bhaktānām bhaktavatsala (with variant bhaktivatsala) is well attested. An early epigraphic reference may be found in the Cchoti Sadri inscription, dated [Vikrama] Samvat 597 (491 CE), which mentions Devī's bhaktavatsalatā: yā bhaktavatsalatayā prabibhartti lokān māteva [svā] kyasutapremnavivriddhasnehā 'who, out of her kindness to her devotees, sustains the worlds just like a mother full of tenderness arising from her affection to her own children' (Sircar, EI 30: 120-127, verse 2cd). BhavP 1.177.25d has given the pāda a Saura twist: ādityārādhane ratā.

${ }^{9}$ As a war god, Kārttikeya-Skanda is associated with the colour red. Mann (2012: 92), commenting on Kārttikeya's red colour, writes: 'Skanda as a red-coloured being fits his Graha-like character, but not his auspicious Senāpati character.' This argument does not seem very convincing and the present passage certainly does not contain any hints that Skanda is invoked here as a Graha.

${ }^{10}$ A similar phrase is used with reference to Kṛ̣ṇa in HV 62.10ab, *721:21, HV App. I, No. $11,{ }^{*} 8$ and ViDh 19.18a. 
Rudra, ${ }_{11}^{11}$ worshipped by the gods, Kārttikeya, of great splendour, solely intent on granting boons - may he constantly bestow peace, power and welfare on me, always! (10-12)

\section{[Nandīśa}

Wearing a garment of white cloth, three-eyed, with a beautiful golden lustre, ${ }^{12}$ a trident in his hand, ${ }^{13}$ very wise, Nandiśa, devoted to Siva, constantly intent upon worship of Śiva, solely intent upon meditation upon Siva - may he, appeased, bestow peace on me, and supreme resolve towards the [Śiva] dharma! $!^{14}\left(13^{-14}\right)$

\section{[Vināyaka]}

With a big belly, a big body, a skin like a heap of smooth collyrium, ${ }^{15}$ endowed with a single tusk ${ }^{16}$ the god who has an elephant head, very powerful, invested with the sacred thread of a snake, adorned with snakes as ornaments, the support of the accomplishment of all aims, overlord of the Ganas, granter of boons, son of Rudra, ${ }^{17}$ god, leader, Vināyaka may he bestow great peace and success in action for me always! $!^{18}\left(15^{-17}\right)$

${ }^{11}$ A reference to the complex birth of Skanda, as narrated, for example, in the Mahābhärata and the Rāmāyaña.

${ }^{12}$ After this, $\mathrm{N}_{58}^{K}$ adds: 'devoted to Rudra, great Yogin, his mind solely dedicated to Rudra' (corr. rudraikāhitamānasaḥ).

${ }^{13}$ I take śülapannir to be short for triśūlapāṇir. Nandin's main attribute is the triśüla.

${ }^{14}$ Nandīśvara is invoked here as the promulgator of the Śivadharma.

${ }^{15}$ I have not found other textual references to Vināyaka's dark body. Could this relate to his birth from the dirt (mala) of Pārvatī's dark skin or simply to the colour of an elephant in general?

${ }^{16}$ Alternatively this may be taken as an inverted bahuvrihi: 'with a gigantic single tusk'.

${ }^{17}$ Elsewhere I have argued that the reference to Vināyaka as 'Rudra's son' could be significant for the dating of the text (Bisschop 2010: 244). Early Purānas, such as the Vãyupurāna and the Skandapurāna, do not yet regard him as the son of Śiva and Pārvatī. There is, however, one exception: in SP 32.116 , in a hymn of praise, Devī is addressed as the mother of Skandacandra and Hastivaktra. On the other hand, there is no reference to this in the rest of the text, which could indicate that this notion may have started to spread around the time of composition of the Skandapurāna. On the adoption of Vināyaka/Gạ̣eśa as a member of Śiva's household, see SP IIB: 50, n. 147, and Törzsök 2004.

${ }^{18}$ The manuscript tradition is divided in $17 \mathrm{~d}$. The repetition of $m e(17 \mathrm{c})$ in $m e$ sada (17d) may have led to the smoother sarvadā in several manuscripts. 


\section{[Mahākāla]}

Resembling sapphire, three-eyed, with a blazing trident and [other] weapons raised, ${ }^{19}$ wearing a red garment, eminent, with a black body, adorned with snakes - may Mahākāla, very powerful, bestow great peace on me, ${ }^{20}$ removing evil, unequalled, destroying the taint of misfortune! ${ }^{21}(18-19)$

\section{[Ambikā]}

Wearing a garment of yellow cloth, with the appearance of a girl, well-adorned, mother of the Ganas, ${ }^{22}$ Ambikā, three-eyed, auspicious, white (Gaurī), mistress of the gods, causing all success, the goddess, intent upon favour, supreme - may the Mother bestow peace on me and quickly grant success! (2O-21)

\section{[Mahāmahiṣamardan̄̄]}

With a smooth dark colour, ${ }^{23}$ Mahāmahișamardanī (Crusher of the Great Buffalo), she who strikes with bow and discus, bearing a sword and a spear, ${ }^{24}$ with one hand raised in threat, ${ }^{25}$ destroying all misfortunes,

${ }^{19}$ For the iconography of Nandíśvara and Mahākāla, see Goodall et al. 2005: 102-108.

${ }^{20}$ The manuscripts show quite some variation, with several of them suggesting pritena cetasā (including also the parallel in the Bhavișyapurāna), in which case, however, Mahākāla is not mentioned by name.

${ }^{21}$ The compound alakșmimalanāśana, also found in $73 \mathrm{~d}$, reappears in the Śivadharma corpus in SiUp 5.1, with reference to the bath in ashes.

${ }^{22}$ For Ambikā/Gaurī as mother of the Gaṇas, cf. SP 60.4ob (ganamātā gaṇāmbikāa). See also Coburn 1984: 98-106.

${ }^{23}$ The fact that the Warrior Goddess is described here as dark-skinned may be relevant for the time of composition of the text, for it shows that it was not yet influenced by the Devīmāhātmya. According to the Skandapurāṇa Kauśikī-Mahișāsuramardinī emerged from the dark skin left behind by Pārvatī, but in the Devīmāhātmya the colour scheme is reversed. See Yokochi 1999: 83-84.

${ }^{24}$ The bow does not occur in the earliest images of Mahișāsuramardinī, but it is found on the images executed in caves 6 and 17 at Udayagiri around the beginning of the fifth century (Harle 1971-72: 45; Yokochi 1999: 77). $\mathrm{P}_{32}^{T}$ has a significant variant: instead of the sword (khadga) and the spear (pattisa), it mentions the conch (śankha), stick (yastit) and knife (asi). The conch as one of her attributes appears to be characteristic of the Deccan (Yokochi 1999: 71). Schmid (2003: 27-29) observes that the earliest in situ images of Mahișāsuramardinī are found in a Vaiṣnava context and that it is only from the sixth century onwards that this form of the Goddess gets associated with Śaivism.

${ }^{25}$ The manuscripts are divided, with some suggesting rather a separate feminine 
mother of all happiness - may she constantly act auspicious towards me! (22-23)

$$
\text { [Bhṛngiriți] }
$$

With a body without flesh, composed of sinews and bones, completely emaciated, very mighty, three-eyed, the great Bhṛngiriți, ${ }^{26}$ son of Rudra, great hero, his mind solely directed towards Rudra - may he too, with a peaceful disposition, quickly bestow peace on me! (24-25)

\section{[Caṇ̣eśvara]}

The fierce general of the Ganas, who holds the great shaft of an axe, ${ }^{27}$ his

$\bar{a} \operatorname{tarjani}$ (also supported by the Bhavisyapurāna parallel), which should then be taken in the sense of tarjani 'threatening'.

${ }^{26}$ The reference to the emaciated Bhṛngiriți/Bhṛngin is significant. His name is not attested in literary works before the Skandapurāna (Bisschop 2010: 244-246). The emaciated figure identified as Bhṛngin begins to appear in material culture in the caves of Elephanta, Ellora, Badami and Aihole from the sixth century onwards (Bautze-Picron 2010: 104-107). The first epigraphical reference to Bhṛngin appears in the second verse of the Senakapat stone inscription of the time of Śivagupta Bālārjuna (beginning of the 7 th c.?):

nirdagdho 'py atra netrajvalanakavalanais tāvakīnair manobhūr bhüyo janmānayā te gamita iti rușā rūkșitena tvayeyam |

kiṃ bhoh śambho ranāmbhonidhim adhiśayitā tyajyate lajjyate no bhringìti proktikārī ripur aśami yayā sāvatāt pārvatī vah $\|$ (Dikshit \& Sircar, EI 31: 31-36; Shastri 1995 II, 154-159; normalized)

May Pārvatī protect you, she who subdued [her] adversary Bhṛngin, who is in the habit of speaking: 'Why, oh Śambhu, don't you abandon and shame this woman (i.e. Pārvatī), who is reposing upon the ocean of delight of love-battle, you, stiffened with anger because the Mind-born (Kāma) has been restored to life by her for you, although he had been burned in this world by gulps of fire from your [third] eye?'

The inscription actually reads śrnigiti but, as Yuko Yokochi has suggested to me (personal communication), this is no doubt a mistake for bhrngitti. Dikshit \& Sircar, followed by Shastri, conjecture janmānuyāne, but the inscription appears to read janmānayā te. An alternative conjecture janmānaye 'on the path of rebirth' may be considered.

${ }^{27}$ I have taken akșa in the sense of 'shaft', although this meaning is not reported in the dictionaries. The rosary is already mentioned in $26 \mathrm{c}$, which precludes taking it as short for akșamālā. The manuscripts are unanimous. 
hand fixed to the rosary, three-eyed, the excellent Caṇdeśvara, ${ }^{28}$ remover of fierce crimes, who purifies from killing a brahmin and the like - may the Great Yogin prepare a succession of fortunes for me! ${ }^{29}(26-27)$

\section{[Brahmā]}

Seated on a lotus, resembling a lotus, with four lotus-faces, bearing a water-jar, eminent, worshipped by Devas and Gandharvas, solely intent upon meditation on Śiva, devoted to the true reality of Śiva - may Brahmā bestow peace on me, with the divine Vedic word (brahmaśabda)! $!^{30}(28-29)$

${ }^{28}$ Canḍeśvara has played various roles in Śaivism, as consumer of offerings, punisher of transgressions of Śaiva initiates and, in the South, as super-bhakta who cuts off his father's legs through devotion (after worshipping Śiva with milk, at which his father gets angry). In South India he has a shrine to the northeast of the central icon. Here he appears as general of the Ganas as well as chastiser of crimes. For a general study of Candeśvara, see Goodall 2009. On the broader significance of this description of Caṇdeśvara in the Śivadharmaśāstra, see Bisschop 2010: 240-241.

${ }^{29}$ After this, $\mathrm{E}^{N}, \mathrm{P}_{3^{2}}^{T}$ and $\mathrm{P}_{72}^{T}$ add 12 to 14 pādas, which run approximately (translation largely based on $\mathrm{E}^{N}$ ):

With the [white] splendour of conch-shell, jasmine and the moon, with a blazing emerald around his neck, holding a rosary, standing in front of Śiva, intent upon his own knowledge (= the Śivadharma), four-faced, four-armed, three-eyed, constantly shining, lord of the earth, the god Vṛsa, supreme among all dharmas, carries the lord on his back. Therefore dharma is the master of the world. May Vṛșa, lord of the bulls, bestow peace on me!

This is almost certainly a later addition, as can be gleaned from the different phrasing in the various manuscripts. The addition is also found in several of the single-text manuscripts of the Śantyadhyāya and it is also commented upon in the Sivadharmavivarana (see appendix). The verses may have been added to bring the present passage in line with the set of eight Gaṇeśas known from Śaiva Siddhānta literature (cf. Bisschop 2010: 243). Vrṣa, the bull of dharma, is invoked here as the embodiment of the Śivadharma. $S_{67}^{S}$ has a similar addition, but it takes the subject to be Kṛṣna rather than Vṛ̣a. Its invocation of Kụṣna is preceded by two verses dedicated to the Gaṇa Ghaṇțākarṇa. This Gaṇa is referred to in ŚiDhŚ 8.85 and 8.87. For Ghaṇtākarṇa's iconography in the Agnipurāna see de Mallmann 1963: 60-62.

${ }^{30} \mathrm{Cf}$. ŚiDhŚ 8.81: brahmaṇā brahmaśabdena stūyateyah sadā harah | sa śivaḥ śāsvato devo goṣu mārīn vyapohatu \|. 
[Viṣṇu ]

Seated on Garuḍa (Tārkșya), four-armed, bearing a conch, discus and mace, dark, wearing a yellow garment, ${ }^{31}$ of great power and heroism, the god who is supreme as the body of sacrifice, ${ }^{32}$ the god Mādhava, killer of Madhu, endowed with the grace of Śiva, devoted to meditation on Śiva, destroyer of all evils, destroyer of all demons - may Viṣnu at all times bestow peace on me, with a peaceful disposition! $!^{33}(30-32)$

${ }^{31}$ The yellow garment is also listed as a characteristic of Viṣnu's appearance in Bṛhatsaṃhitā $24.18 \mathrm{c}$ and $58.32 \mathrm{ab}$. Bṛhatsaṃhitā 58.34 further specifies that a four-armed image of Vișnu should have the conch and discus in the left hand and the mace and śäntimudrā in the right hand. Instead of the śäntimudrā, the more common attribute from the Gupta period onwards is the lotus (Shastri 1969: 134). No fourth attribute is mentioned in the Śivadharmaśāstra. Cf. also 'Kāśyapa' quoted by M.R. Bhat (1982: 562) from Utpaladeva's commentary on the Bṛhatsaṃhitā: viṣnuś caturbhujaḥ śārngī śañkhacakragadādharah | śrìvatsānkaḥ pìtavāsā vanamālāvibhūṣitaḥ || (the last pāda is shared with the variant in $\mathrm{P}_{32}^{T}$ and $\mathrm{P}_{7^{2}}^{T}$ ).

$3^{2}$ Alternatively, yajñadehottamo may be taken to mean 'supreme with a body consisting of sacrifice'. The close relation between Viṣnu and sacrifice is well established, as in the notions of yajñavarāha and yajñapurușa. Perhaps this is a reference to Viṣnu as the supreme Purușa, whose body constitutes the sacrifice in the Purușasūkta (Rgveda 10.90).

${ }^{33}$ A large number of manuscripts omit $32 \mathrm{bc}$. The wide distribution of readings in the ending of $32 \mathrm{a}$ may be related to this omission as well.

After this verse, $E^{N}$ and $S_{67}^{S}$ add 30 pādas dedicated to Arhant, Buddha, Jayā/Vijayā, Pṛthivī (Dharitrī) and the cows of Kṣīroda. There are significant differences in phrasing. $\mathrm{N}_{58}^{K}$ has a similar addition, of 34 verses, dedicated to Arhant, Buddha, Vṛșabha, and the five cows in Śivapura (Nandā, Subhadrā, Surabhī, Suśīlā, Sumanā). The following provisional translation is based largely on $\hat{S}_{67}^{S}$ :

The Arhant, the god with a peaceful form, a feather-brush and a cloth in his hands, naked, covered with dust and mire $\left(\mathrm{E}^{N}\right)$, steady-minded and concentrated, his eyes turned inwards, peaceful, contemplating only the knowledge of Śiva - may he, appeased, endowed with oneness with Śiva, bestow peace on me!

In control of his senses, absorbed in intense concentration, adorned with a vessel and a monk's robe, his fingers in the gestures of granting a boon and freedom from fear, always delighting in reflection on knowledge, furnished with yogic perception, devoted to the knowledge of Śiva - may the Buddha, delighting in the welfare of all beings, bestow peace on me! 


\section{$[\text { Mātṛs }]^{34}$}

\section{[1. Brahmāṇī]}

With a ruby-coloured appearance, the goddess with four lotus-faces, her

With a ravishing, very wonderful $\left(\mathrm{E}^{N}\right)$ yellow-coloured body, beautiful in all her limbs, the goddess, Jayā, wishing for victory, constantly delighting in the worship of Śiva, devoted to the worship of Śiva, and the Earth (Dharitrī), mother of the people - may she always protect me!

The Cows arisen from the milk ocean (Kșīroda), desiring the welfare of the people, always delighting the gods and brahmins in particular, furnished with a divine soul - may they always bestow peace on me!

On the adoption of the Arhant and the Buddha in the lists of deities in the Sivadharmaśāstra, see Bisschop forthc. a. Note that the Buddha and the god of the Arhants (arhatām devaḥ) are mentioned in Bṛhatsaṃhitā 58.44-45.

34 The iconography of the Mātrkās described in this section supports a date of the sixth century at the earliest for the composition of the text. For example, the text refers to the Mātṛkās' vehicles, which start to appear in sculpture only from around this time. Among the earliest sets of Mātṛkās with vehicles are the ones from Śāmalājī dated from ca. 520 CE, and two sets from Deogarh (Schastok 1985: 70-71). See also Panikkar 1997, for a historical overview of Mātṛkā iconography. The Kāpālika iconography of the last two Mātṛs is quite striking. Also noteworthy is the addition of an eighth goddess, Lamboșthī, and the mix-up of the regular and well-established order of Vārāhī and Aindrī. Some instances of groups of Mātṛs that do have Aindrī followed by Vārāhī are known, however, e.g.:

1. a broken panel from Nagar, Bharatpur, in Rajasthan, ca. 6th/7th c. CE (AIIS o16855, now at the archaeological museum of the Amber fort outside Jaipur)

2. a set on the Paraśurāmeśvara temple at Bhuvaneśvara, ca. 7th c. CE (Pannikar 1997, plates 104-105)

3. a set on the doorway of a Sūrya temple at Umri, Tikamgarh, in Madhya Pradesh, ca. 825 CE (Meister 1986, fig. 7)

For a table recording different sets of Mātṛkās, see Meister 1997: 234-235 (Meister fails to notice the non-standard order on the Paraśurāmeśvara temple). The standard set of seven mothers derived from male counterparts is not attested in literature before the seventh century. One of the earliest sources is the Skandapurāna, which lists them along with many other Mothers in its Koțivarșa Māhātmya ( $\left.\mathrm{SP}_{\mathrm{Bh}} 171\right)$. One of the earliest iconographical descriptions, along with the present passage, may be MtP 261.24-39. The set of eight rather than seven goddesses is a distinctive Tantric feature (Hatley 2012: 107-108), but note that it also appears in Elephanta in the Mātṛkā shrine in the east wing (Schastok 1985: 62, fig. 117). 
hand fixed on a rosary, bearing a water-jar, auspicious — may Brahmānīi, with a pleasant face, devoted to worship of Śiva, pleased, always bestow peace on me with the Vedic word (brahmaśabda)! ${ }^{35}\left(33^{-34}\right)$

\section{[2. Rudrānīī]}

Resembling the mountain of snow [in whiteness], the goddess riding on a great bull, a trident in her hand, granter of boons, adorned with ornaments of snakes, four-armed, four-faced, three-eyed, remover of evils may Rudrāṇī, pleased, blazing constantly, remove pain for me! $\left(35^{-36}\right)$

\section{[3. Kaumārī]}

Riding on a peacock, the goddess with a body red like vermillion, a lance in her hand, of majestic appearance, adorned with all decorations, devoted to Rudra, of great strength, always delighting in worship of Rudra - may Kaumārī, granter of boons, the goddess, quickly bestow peace on me! $(37-38)$

\section{[4. Vaiṣnavīi}

With a conch, discus and mace in her hand, dark, fond of the yellow garment, four-armed, riding on Garuḍa (Tārkṣya), Vaiṣnavī, worshipped by the gods, always delighting in the worship of Śiva, her mind solely directed to Śiva - may she constantly bestow peace on me, destroying all demons! (39-40)

$$
[5 \cdot \text { Aindrī }]^{36}
$$

Mounted on the elephant Airāvata, a thunderbolt in her hand, very powerful, adorned with a thousand eyes, with a golden lustre, venerated by Siddhas and Gandharvas, adorned with all ornaments - may the goddess Aindrī at all times quickly bestow peace on me! (41-42)

35 The invocation is very similar in style to that of Brahmā at 28-29 above. The same is the case for the other Mātrs, with many adjectives taken over from their male counterparts. The invocations of the mothers in this section are clearly inspired by the earlier invocations of the male deities and as such do not necessarily provide independent evidence for sculptural representations.

${ }^{36}$ These two pādas are placed after Vārāhī $(44)$ in $\mathrm{N}_{58}^{K}, \mathrm{P}_{32}^{T}$ and $\mathrm{P}_{72}^{T}$, thus making the sequence of the Mātṛkās conform to the regular standard. 


\section{[6. Vārāhī]}

With the snout of a boar, dreadful, riding a supreme boar, dark, pure and massive, with the conch, discus and mace as her weapons, ${ }^{37}$ always threatening obstacles, always worshipping Śiva — may Vārāhī, granter of boons, the goddess, grant peace and health to me! (43-44)

\section{[7. Cāmuṇụā $]$}

With upraised hair, hollow-eyed, without flesh, bound by sinews, with a gaping mouth, terrible, ready with a sword and a dagger, with a garland of skulls, angry, wearing a magnificent skull-staff, with eyes all red and yellow, covered with an elephant hide, her body encircled by various snakes, dwelling at the cremation ground, with a form of Siva that is dreadful,$^{38}$ creating fear with the cries of jackals $\left(s_{i} i \bar{a}\right)$ - may Cāmuṇ̣ā, with a terrible form (caṇdarūpa), grant great protection to me! ${ }^{39}\left(45^{-47)}\right.$

\section{[8. Lamboșțhī]}

With a fat body, adorned with various ornaments, threatening obstacles, bearing a sword with a blazing tip, seated on a crow, great heroine, de-

37 These Vaiṣnava attributes are found on several surviving Vārāhī sculptures. For Vārāhī riding a boar, see Rangarajan 2004: 97-100.

${ }^{38}$ In other words, she has a Bhairava appearance.

${ }^{39} \mathrm{~N}_{58}^{K}$ adds two more pādas on Cāmuṇḍā after $47 \mathrm{c}$, while $\mathrm{P}_{3^{2}}^{T}$ and $\mathrm{P}_{7^{2}}^{T}$ add two similar pādas after $47 \mathrm{C}$ and two more pādas after $47 \mathrm{f}$. No vehicle is mentioned for Cāmuṇ̣ā, but the reference to the cries of jackals may point to the presence of a jackal (see Schastok 1985, fig. 3 and 9). The name Cāmunḍā appears in texts from about the sixth to the seventh century CE. The earliest textual evidence may be a passage in Bhāviveka's Tarkajvālā, which condemns the coarse ritual knowledge of Cāmuṇ̣̂ā (Kapstein 2003: 243, 249). See also Harșacarita p. 304, l. 3, referring to Cāmuṇ̣̂a shrines. The name may have been standardized because of the popularity of the Devimāhätmya, in which she is the killer of Caṇda and Muṇda. The Skandapurāna does not mention the name Cāmuṇụā, but in its Koțivarșa Māhātmya ( $\left.\mathrm{SP}_{\mathrm{Bh}}{ }_{171}\right)$, about the birth of the Mothers, it includes the standard seven Mothers, among which a goddess named Bahumāṃā takes the position of Cāmuṇ̂ā. See Bakker (2014: 255-256), who considers the passage to be 'the earliest textual reference to the standard Seven Mothers, notwithstanding the fact that images testifying to this iconography have made their appearance since the fifth century'. 
stroying all evils — may Lamboșțīi (she who has full lips), ${ }^{40}$ granter of boons, the goddess, bestow peace on me! (48-49)

\section{[All Mātṛs]}

The divine Mothers of the sky, and other Mothers of the world, all Mothers of spirits, and the other Mothers of the demons, all the Mothers who are great goddesses, their hands occupied with their own weapons, who stay around, pervading the world, eager for bali offerings, highly fortunate, devoted to Rudra, great heroines, their minds dedicated to the worship of Rudra - may the Mothers, worshipped by the gods, constantly bestow peace on me! $\left(5^{\circ}-5^{2}\right)$

\section{[Rudras, Mātṛs and Gaṇādhipas]}

The Rudras of fearsome deeds who dwell at the abodes of Rudra, and those special ones who are gentle, dwelling at the abodes of Sthānu, and the Mothers with a fearsome appearance, and they who are Lords of the Ganas, and others who may be obstacles, dwelling in the main and intermediate directions - may they all, with satisfied minds, accept my bali offering. May they quickly grant success! May they always protect me from dangers! ${ }^{41}\left(53^{-} 55\right)$

${ }^{40}$ The invocation of Lamboșthī occurs only in the Nepalese manuscripts, with the exception of $\mathrm{N}_{45}^{C}$ ( $\mathrm{N}_{77}^{K o}$ is not available because of loss of a folio), and it is also missing in the Bhavisyapurāna parallel. While this may suggest an early addition in the Nepalese transmission of the text, it is also conceivable that the two verses were omitted later, when the group of Saptamātṛka had been well established, which did not include a goddess Lambosthī. Groups of eight are a common feature of the invocations in the Śantyadhyāya. On the addition of an eighth goddess to the standard set of seven, see Hatley 2012: 107-108, but in the texts he cites, the eighth goddess is named Mahālakșmī, Bhairavī or Yogeśvarī. Lamboșṭhī's appearance is the reverse of Cāmuṇ̣̂ā. SP 68.2 associates the goddess Lambaușthī (along with Vṛṣadamśāa and Kiṃnarī) with the country of Siṃhala. In form and appearance she strongly resembles the goddess Jyeșțhā, who was particularly popular in South India and who is also fat, has drooping lips (lamboșțī), and is accompanied by a crow (Leslie 1991). No images of a Jyeșthā-like goddess from the North are known.

${ }^{41}$ Verses 53-55 appear almost verbatim in Mrgendra, Kriyāpāda 7.33-35, in a section on the offering of bali. Also İśānaśivagurudevapaddhati, Sāmānyapāda 14.178-180ab = Mantrapāda 28.96cd-98 = Kriyāpāda 15.4-16ab. Variants of these verses are also found in several later Tantric sources, including the works of Aghoraśiva and Bhoja (TAK 4 


\section{[Ganas: E]}

The Ganas who are in the eastern (Indra's) direction, thunderbolts in their hands, ${ }^{42}$ very powerful, very white-eyed, white in appearance, white coppery, ${ }^{43}$ in heaven, in the sky and on earth, and dwelling in the bottom of the Pātāla, thrilled, delighting in the worship of Rudra - may they always bestow peace on me! $\left(5^{6-57)}\right.$

[Gaṇas: SE]

All the Ganas in the southeastern (Agni's) direction, ladles in their hands, bearing quivers, very red-eyed, red in appearance, red coppery, in heaven, in the sky and on earth, and dwelling in the bottom of the Pātāla, their minds bent to Rudra - may they always bestow peace on me! (58-59)

\section{[Gaṇas: S]}

The Ganas in the southern (Yama's) direction, always with sticks in their hands, black, black in appearance, angry, black coppery, in heaven, in the sky and on earth, and dwelling in the bottom of the Pātāla, their minds solely devoted to Rudra - may they always bestow peace on me! (6o-61)

forthc., s.v. balimantra). The reference to bali provides a hint to the ritual activity accompanying the invocation. Early epigraphical attestations for the offering of bali are found in the Bagh copper plates of the fourth-century Valkhā king Bhuluṇda (Ramesh \& Tiwari 1990). See Willis 2009, 102-104 (with references and an image of a fifth-century balipițha from Rāmgarh, near the Gupta site Badoh).

${ }^{42}$ The appearance of the Ganas in the different directions is modelled after the iconography of the deity who is the guardian of each direction. İsānaśiva prescribes the use of the invocation of the Ganas of the ten directions (56-75) on several occasions in the Kriyāpāda of his İśānaśivagurudevapaddhati (Siddhāntasāra), abbreviating it by citing only the first two pādas, dedicated to the Gaṇas in the east. He gives the full version of the mantra in Mantrapāda 30.84, but in a modified prose form. See the register of testimonia in the edition.

43 The qualification lohita is applied to each group of Ganas of the different directions but in combination with different colours. I take lohita to mean 'coppery' or 'of copper appearance' here. See also the comment in the Sivadharmavivarana: 'Even though there is a distinction of colours, extension of [the designation] "coppery" (lohita) should be understood for each of the [Ganas] addressed after the statement "in the eastern direction" (56e).' 
[Gaṇas: SW]

The Ganas in the southwestern (Nirrti's) direction, angry, demonic, with swords in their hands, ${ }^{44}$ very dark-eyed, with a dark appearance, dark coppery, in heaven, in the sky and on earth, and dwelling in the bottom of the Pātāla, delighting in meditation on Rudra — may they always bestow peace on me! (62-63)

\section{[Gaṇas: W]}

The Ganas who are in the western (Varuna's) direction, always with nooses in their hands, very dark-eyed, with a dark appearance, dark coppery, in heaven, in the sky and on earth, and dwelling in the bottom of the Pātāla, delighting in worship of the supreme lord - may they always bestow peace on me! (64-65)

\section{[Ganas: NW]}

The Gaṇas in the northwestern (Vāyu's) direction, ${ }^{45}$ always with banners in their hands, very yellow-eyed, with a yellow appearance, yellow coppery, in heaven, in the sky and on earth, and dwelling in the bottom of the Pātāla, dedicated to devotion of Śiva - may they always bestow safety upon me! (66-67)

\section{[Gaṇas: N]}

The Ganas in the northern direction, always with treasures in their hands, ${ }^{46}$ with flecked eyes, with flecked appearance, ${ }^{47}$ flecked coppery, in heaven, in the sky and on earth, and dwelling in the bottom of the Pātāla, engaged in the worship of Śiva - may they always bestow safety on me! (68-69)

${ }^{44}$ I follow the reading khadgapannayah of $\mathrm{N}_{58}^{K}, \hat{S}_{67}^{S}$ and $\mathrm{P}_{32}^{T}$. The parallel expression in the İsānaśivagurudevapaddhati also supports it. As in the invocations of the other Ganas we expect a reference to the weapons they hold in their hands. Nirrti's weapon is a sword (Wessels-Mevissen 2001: 99-100).

45 The adopted reading $\left(\mathrm{N}_{82}^{K}, \mathrm{~N}_{12}^{K}, \mathrm{~B}_{99}^{C}\right)$ is hypermetrical. It is possible that vāyaryām was pronounced as vāyvyam and that the different variants have arisen as different attempts to remove it.

${ }^{46}$ The northern direction is associated with Kubera, lord of treasure.

${ }^{47}$ The support for the hypermetrical reading śavalākșạh śavalanibhās is quite strong. As in the case of 66a above, the different variants may represent different attempts to remove it. 


\section{[Gaṇas: NE]}

The Gaṇas in the northeastern (İsāna's) direction, calm, with tridents (śüla) in their hands, fine, with a very fine appearance, fine coppery, in heaven, in the sky and on earth, and dwelling in the bottom of the Pātāla, engaged in the worship of Śiva - may they always bestow safety on me! $(70-71)$

\section{[Gaṇas: Below]}

The Ganas who are in the lower part, always with tridents in their hands, smoky, with a smoke-coloured appearance, smoke-coppery, in heaven, in the sky and on earth, ${ }^{48}$ and dwelling in the bottom of the Pātāla may they constantly bestow peace on me, destroying the taint of misfortune. ${ }^{49}(72-73)$

\section{[Ganas: Above]}

The Ganas who are in the upper part, of great power and heroism, very fine-eyed, with a fine appearance, fine coppery, in heaven, in the sky and on earth, and dwelling in the bottom of the Pātāla, engaged in the worship of Śiva - may they destroy misfortune for me! (74-75)

${ }^{48}$ This stereotypical phrase, which is appropriate in the previous descriptions of Ganas in the eight different horizontal directions, does not fit well with the present description of the Ganas in the lower and upper regions of the cosmos, which already involves a vertical division. The Śivadharmavivaraṇa explains: 'Even though they are stationed in the regions of "the lower part" (72a) etc., pervasion of all worlds should be understood because of their sovereign power.'

${ }^{49}$ In contrast to the previous invocations, the descriptions of the Ganas in the lower and upper part of the cosmos show no association with a particular deity. The tridents said to be in the hands of the Ganas in the lower part may be due to the influence of the description of the Ganas the northeastern direction, mentioned just before. In later Tantric Śaiva sources Brahmā is associated with the upper part and Viṣnu with the lower part (TAK III, s.v. dikpatayah). The Southern transmission of the text appears to have updated the text accordingly, with the Ganas in the lower part bearing discuses in their hands (cakrapānayah) and the ones in the upper part bearing lotuses (padmapannayah, $\left.\mathrm{P}_{7^{2}}^{T}\right)$. The same also applies to the mantra in the Iśánaśivagurudevapaddhati. 


\section{[Ganas: Conclusion]}

Having worshipped Śiva with effort, one should scatter a bali offering for these Ganas,,$^{50}$ great souls, of great power and heroism. Thereupon, with satisfied minds, may they always bestow peace on me! $!^{5^{1}}(76)$

$$
[\text { Dikpālas }]^{52}
$$

\section{[Indra in Amarāvatī]}

The city called Amarāvatī is established in the eastern part, crowded with Vidyādharas, visited by Siddhas and Gandharvas, brilliant with a bejewelled wall, decorated with all jewels. There reigns the Lord of the gods (Indra), eminent, thunderbolt in hand, very powerful, with a thousand beautiful eyes, mounted on the elephant Airāvata, golden-coloured, ${ }^{53}$ of great splendour, chief of the gods, constantly pleased, delighting in the worship of the Supreme lord, possessed of meditation on Siva, endowed with devotion to Siva, dedicated to bowing to Śiva - may he bestow peace on me! $(77-80)$

${ }^{50}$ Note again the reference to the ritual act of scattering a bali offering.

${ }^{11} \mathrm{~N}_{5^{8}}^{K}$ adds two more pādas to create two four-pāda verses.

$5^{2}$ The following list of eight Dikpālas and their abodes corresponds to the canonical list given in Kirfel 1967: 95 (with either Virūpākṣa or Nirṛti in the southwest). For other textual descriptions of the towns, which are located on Mt Meru, see Bhuvanavinyāsa 2.43.8-17 (Kirfel 1954: 98-99). In the epics, only four Dikpālas are mentioned (Wessels-Mevissen 2001: 12-13). It is only from the time of the Purānas that we find the tradition of eight Dikpālas attested, but with quite a lot of variation (see table X [p.15] in Wessels-Mevissen 2001). The earliest dated literary evidence for the eight Dikpālas is to be found in Varāhamihira's Yogayātrā (Wessels-Mevissen 2001: 15 and table XI). Another possibly early reference is Amarakośa 1.3.178-179. The present passage, not drawn upon by Wessels-Mevissen, may be one of the earliest detailed descriptions of the eight Dikpālas. Varied sets of the eight Dikpālas start to appear for the first time in the Deccan towards the end of the sixth century, while the complete canonical set is only attested from the middle of the seventh century onwards (Wessels-Mevissen 2001: $23 \mathrm{ff}$.).

${ }^{53}$ For Indra's golden appearance, cf. VDhP 3.50.3a and 3.50.8ab. 


\section{[Agni in Tejovatī]}

In the direction of Agni (southeast) is the beautiful city Tejovatī, ${ }^{54}$ crowded with various deities, blazing with the light of jewels. There, his body surrounded by flames, with a splendour equal to blazing charcoal, causing the welfare of embodied souls, may the god who is flaming (Jvalana), destroying evils, engaged in the muttering and worship of Śiva, devoted to recollection of Śiva, bestow peace on me and destruction of evils! (81-83)

\section{[Yama in Vaivasvatī]}

The city called Vaivasvatī is established in the south, the abode of Pitrrs, Rakșas and Uragas, and an array of hundreds of Suras and Asuras. There, with the appearance of sapphire, with elongated eyes that are red at the ends, mounted on a great buffalo, adorned with a black garland and cloth, may Yama, of great splendour, devoted to the Law of Śiva, engaged in the worship of Śiva, grant me peace and health! (84-86)

\section{[Nirṛti in Kṛ̣ṇ̄ā]}

In the direction of Nirrti (southwest) is the famous town called Kṛ̣nāā, 55 crowded with great Rakṣases and Gaṇas, filled with Piśācas and Pretas. There, with the appearance of a dark cloud, adorned with a red garland and cloth, sword in hand, of great splendour, ablaze with wide open mouth, may the lord of Rakșas, Nirrti, ${ }^{56}$ always delighting in the worship of Siva, continuously bestow great peace on me, eager for devotion to Śiva! (87-89)

\section{[Varuṇa in Śuddhavatī]}

In the western direction is the splendid city Suddhavatī, crowded with various Gaṇas, filled with many Kimnaras. There, with the appearance

${ }^{54}$ Bhuvanavinyāsa 2.43.14ab has the variant Tejasvinī as the name of Agni's city: tejasvinì nāma purī āgneyyām pāvakasya tu.

${ }^{55}$ Bhuvanavinyāsa 2.43.16ab refers to this city as Śuddhavatī: nairṛte krșnavarṇā ca tathā śuddhavatì śubhā.

${ }^{56}$ The manuscripts are divided between the spelling Nirṛti and Nairṛti. 
of pearl, ${ }^{57}$ with eyes all tawny, with a bright cloth and garment, ${ }^{58}$ a noose in his hand, very powerful, may Varuna, with supreme devotion, his mind solely dedicated to Śiva, constantly destroy disease, grief, injury and pain for me! ${ }^{19}(90-92)$

\section{[Vāyu in Gandhavatī]}

In the northwestern (Vāyu's) direction is the splendid city Gandhavatī, inhabited $^{60}$ by Ṛșis, Siddhas and Gaṇas, with a golden wall and doorway. There, with a copper-coloured body ${ }^{61}$ his eyes dark and tawny, holding onto an inflated cloth, furnished with the flagstaff as his weapon, ${ }^{62}$ may the Wind (Pavana), the supreme god, devoted to Parameśvara, bestow safety, health, power [and] peace on me always! (93-95)

\section{[Kubera in Mahodayā]}

In the north is the city called Mahodayā, very luminous, crowded with many Yakșas, embellished with various jewels. There, may the god, with

\footnotetext{
57 Varuṇa should have the colour of lapislazuli (snigdhavaidūryasañkäśậ) according to VDhP 3.52.1c.

${ }^{8}$ Cf. VDhP $3 \cdot 5^{2.1}$ śvetāmbaradharas tathā.

59 The adopted reading receives only limited support. Several manuscripts point to a plural nirnāśayantu, but the plural is not fitting here.

${ }^{60}$ I take adhyușta as metri causa for adhyușita. The variant readings may represent different attempts to correct it.

${ }^{61}$ According to $\operatorname{VDhP} 3.58 .1 a$, Vāyu has the colour of the sky: vāyur ambaravarnas tu.

${ }^{62}$ The interpretation of the compound pațaryāptāntarālina is uncertain, but one of Vāyu's iconographic attributes is an inflated cloth. Cf. VDhP 3.58.1c: vāyvāpūritavastra. See Wessels-Mevissen 2001: 102-103, for examples from sculpture. I take the first three members of the compound as an inverted bahuvrini: 'holding onto a cloth whose inside is pervaded [by wind]'. The Śivadharmavivarana rather takes it to mean 'dwelling in the space that is enveloped in a cloth'. Wessels-Mevissen distinguishes between a 'cloth type' of Vāyu that is North Indian and a 'flag type' that is South Indian, but she also draws attention to a sculpture on the Bāla Brahmā and Svarga Brahmā temples at Ālampur, dated to the second half of the seventh century $\mathrm{CE}$, which includes a 'rare combination of the cloth and the flag' (figures 68 and 75). The same combination is also suggested by the present invocation. The various sets of Dikpālas from Ālampur in general show great correspondences in form with the descriptions in the present invocations. For example, the text only mentions the vähanas of Indra and Yama, while the sculptures from Ālampur only depict the vāhanas of Indra, Yama and Nirrti and not those of any of the other Dikpālas (Wessels-Mevissen 20o1: 39-44). The Navabrahmā temple group as a whole shows a strong interaction of both North and South Indian artistic idioms.
} 
a mace in his hand, adorned with a colourful garland and cloth, shortarmed, of great splendour, eyes all tawny, Kubera, granter of boons, prosperous, delighting in the worship of the feet of Hara, bestow peace on me, being pleased, peaceful, with a delighted mind! (96-98)

\section{[İsāāna in Yaśovatī]}

The beautiful city Yaśovatī is established in the northeastern (İsāna's) direction, crowded with various Ganas, inhabited by many gods, surrounded by a luminous wall, unequalled, very eminent. There, may he too, with the appearance of pearl, decorated by the moon, three-eyed, with a peaceful form and self, bearing a rosary, ${ }^{63}$ Hara, İsāna, the supreme god, supreme among all gods, bestow peace on me quickly, with his entire self! (99-101)

\section{$[\text { Devas in the Seven Worlds] }]^{64}$}

The gods who dwell in the Bhūloka, the Bhuvarloka, the Svarloka, provided with divine splendour - may they always bestow peace on me! The gods who are present in the Maharloka, the Janarloka and the Tapoloka - may they too, delighted, always bestow peace on me! And the gods in the Satyaloka, their bodies self-luminous, devoted to Śiva, welldisposed - may they destroy danger for me! $!^{65}(102-104)$

\footnotetext{
${ }^{63}$ Surprisingly, no mention is made of the triśūla, İsāna's major attribute.

${ }^{64}$ On the seven worlds, see Kirfel 1967: 128.

${ }_{55}$ After this, $\mathrm{N}_{58}^{K}$ and $S_{67}^{S}$ add some more verses on the appearance of the gods in these seven worlds (in reverse order) and their devotion to Śiva. In the version of $\hat{S}_{67}^{S}$ :

The gods in Tapoloka, their bodies blazing like crystal, devoted to Rudra, great souls - may they always bestow peace on me! And the gods in Janaloka, shining like purified gold, bowing down to İsāna — may they always bestow peace on me! And the gods in Mahalloka, resembling refined gold, delighting in the worship of Śiva - may they provide security for me, always! And the gods that are in Svarloka, of shining colour, very powerful, bent towards Śaṃkara - may they provide victory for me! And the gods in Bhürloka, illuminating the ten directions, their minds dedicated only to Śiva - may they extinguish danger for me!
}

These verses are clearly secondary. Similar passages occur in $\mathrm{P}_{32}^{T}$ after 102d (originally placed after 1ogb) and in $\mathrm{P}_{72}^{T}$ after 103d. 
[Devas in Caves, Forests etc.]

The gods who dwell on mountains, in caves, strongholds and in forests, devoted to the worship of Rudra - may they always grant protection to me! ${ }^{66}(105)$

[Sarasvatī]

With a body white like the rays of the moon in autumn, with spotless splendour - may Sarasvatī, devoted to Śiva, quickly bestow peace on me! (106)

$$
\text { [Śrīi }
$$

With a beautiful golden complexion and a bud in her lotus hand - may the goddess Śrī, devoted to Śiva, grant prosperous fortune to me! (107)

$$
\text { [Jayā] }
$$

With a beautiful moon-like face, blazing like brilliant gold - may the goddess Jayā, devoted to Śiva, grant all desires to me! $!^{67}$ (108)

\section{[Aparājitā]}

With a wonderful pearlnecklace, wearing a bright golden girdle ${ }^{68}$ — may Aparājitā, delighting in Rudra, grant victory to me! $!^{69}$ (109)

\footnotetext{
${ }^{66}$ After this, $\mathrm{E}^{N}$ adds four verses about the seven subterranean regions (Talas): Mahātala, Rasātala, Talātala, Sutala, Nitala, Vitala and Tala.

${ }^{6} 7$ After this, $S_{67}^{S}$ adds six more pādas, invoking Vijayā and Jayantī, thus completing the group of the four sisters of Tumburu: Jayā, Vijayā, Jayantī and Aparājitā. See Goudriaan 1973 .

68 The manuscripts are divided between bhāsvatkanakamekhalā, which receives support from the Bhavișyapurāna parallel, and bhāskaroijvalatejasā.

69 Aparājitā is an epithet of Kauśikī/Vindhyavāsinī in the Skandapurāna and Vindhyavāsinī is presented like a daughter of Śiva and Pārvatī in that text. This myth may have been transmitted in a small Śaiva circle only because, as far as we can tell, it is only told in the Skandapurāna (SP III). Note in this connection the variant-but unmetrical—reading rudrasutāparäjitāa. The reading adopted in the edition is hypermetrical, but this may be allowed if we take $a p a$ - as a single syllable, thus yielding a bha-vipulā.
} 


\section{$[\text { Navagrahas }]^{70}$}

[Sūrya: Sun]

With a complexion coloured red like vermillion, ${ }^{71}$ with elongated eyes, furnished with two rays, ${ }^{72}$ riding on seven horses - may he [Sūrya], with a garland of rays, the blessed one, delighting in the worship and praise of Śiva, bestow great peace on me, warding off injury from the planets! (110-111)

\section{[Soma: Moon]}

Bringing about the prosperity of the world, ${ }^{73}$ cooling with the vessel of

$7^{\circ}$ The invocation of the planets follows the temporal order of the seven days of the week, which was established in India by the fourth century. See Pingree 1965 and Yano 2004. Material representations of the planets as a group start to appear from the second half of the fifth century, with Ketu being absent until ca. 6oo CE. They become significantly more numerous from the second half of the seventh century (Markel 1995: 94-95, 100). The first lintel depicting all nine planets comes from Uttar Pradesh (Markel 1995: figure 21). Markel (1995: 164) argues that the astrological verses in MtP 94.1-9 (included in his appendix, pp. 189-19o) would be the first source that gives 'anthropomorphic descriptions of the planetary deities in the group known as the navagraha', dating the passage, on debatable grounds, to the sixth century. He finds the first evidence for the addition of Rāhu and Ketu to the sun, the moon and the five conventional planets, to form the navagraha, in the mid-sixth century Bṛatsaṃhitā. Varāhamihira, following Garga, is the first Jyotișa author to devote considerable portions of text to Rāhu and Ketu. See p.16. The nine planets are also mentioned several times in his earlier work, the Yogayātrā, for example in Yogayātrā 3.19-21 (on these two verses, see Pingree 1959). For a study of the navagrahaśānti, see Bühnemann 1989 .

${ }^{71} \mathrm{Cf}$. VDhP 3.67.2b sindūrāruṇasaprabhaḥ 'with a lustre red like vermillion'. Note that -aruna-is also found as a variant reading in several manuscripts.

$7^{2}$ I follow the reading of $\mathrm{N}_{82}^{K}, \mathrm{~N}_{12}^{K}, \mathrm{E}^{N}$ and $\hat{S}_{67}^{S}$. The variant reading 'thousand-rayed' (sahasrakiranah) appears to be the lectio facilior, although it receives support from the parallel in the Bhavisyapurāna. In sculptures from the Gupta period onwards, Sūrya is portrayed with two lotus buds or two full-blown lotuses in his hands. See Markel 1995: 30. This iconographic feature is also described in most of the textual sources (e.g. Brhatsam hitā 58.47ab), but VDhP 3.67.4 states that he should be depicted with the reins (raśmayah) held in both of his hands. Could it be that kiraña should be understood here to denote the reins? $\mathrm{N}_{58}^{K}$ adds two pādas after 11od, referring to the two lotuses held in Sūrya's hands.

${ }^{73}$ This is one of the rare cases where $\mathrm{N}_{82}^{K}$ is not supported by $\mathrm{B}_{99}^{c}$. The ending-dhāro (instead of -kara) may have been caused by the presence of -dhära-in pāda b. In addition the hi was probably introduced as a hiatus breaker. 
nectar ${ }^{74}$ - may Soma, with a gentle disposition, drive away injury from the planets! (112)

\section{[Anggāraka: Mars]}

With a body whose limbs are like ruby, tawny-eyed — may Angāraka always drive away injury from the planets for me! ${ }^{75}$ (113)

\section{[Budha: Mercury]}

With a saffron-skinned body, his hand raised with a bow ${ }^{76}$ - may the illustrious Budha, devoted to Śiva, always drive away injury from the planets! (114)

\section{[Bṛhaspati: Jupiter]}

With a metallic golden complexion, ${ }^{77}$ abiding in all knowledge, ${ }^{78}$ Brhhaspati, at all times devoted to the praise of İsāna - may he too, furnished with a supreme peaceful mind, having defeated injury from the planets, bestow victory always! $\left(115^{-116)}\right.$

\section{[Śukra: Venus]}

With a [white] splendour equal to snow, jasmine and the moon, worshipped by the Suras and the Daitya lords ${ }^{79}$ — may Śukra, delighting in the praise of Śiva, drive away injury from the planets. (117)

${ }^{74}$ See Markel 1995: $36-37$ on this attribute of the Moon.

${ }^{75}$ After this, $\mathrm{P}_{32}^{T}$ and $\mathrm{P}_{72}^{T}$ add a verse about Angāraka's devotion to Rudra. Some of the other invocations of the planets add an adjective referring to their devotion to Siva and it is thus easily explained why someone would have felt the need to add this verse here.

${ }^{76}$ The readings in 114 ab show much variation and the adopted reading is by no means certain. The reference to Budha's bow only occurs in $\mathrm{N}_{82}^{K}, \mathrm{~N}_{58}^{K}, \mathrm{E}^{N}$ and $\mathrm{B}_{99}^{C}$. See Markel 1995: 41-44 for the depiction of Budha as an archer in Bihari and Bengali representations, observing that 'references to the archer's iconography of Budha are absent in early Brahmanical textual descriptions, except for the Agnipurāna (51.11), which prescribes a bow and a rosary' (p. 42).

${ }^{77} \mathrm{Cf}$. VDhP 3.69.3a taptajāmbūnadākāro 'with the appearance of molten gold'.

${ }^{78}$ Brhaspati is the guru of the gods.

79 This is slightly problematic. Sukra is the guru of the demons and not of the gods. One might consider a conjecture -tulyābho 'suradaityendrapüjitah. In the Bhavisyapurāna parallel the reference to the gods has been removed: daityadānavapüjitah. 


\section{[Śanaiścara: Saturn]}

With a [dark] complexion like a heap of collyrium, with the splendour of deep-red eyes - may Śanaiścara, devoted to Śiva, drive away injury from the planets. (118)

\section{[Rāhu: Eclipser]}

Like black collyrium, eminent, son of Simhikāa, ${ }^{80}$ very powerful — may Rāhu, devoted to the worship of Śiva, drive away injury from the planets. (119)

\section{[Ketu: Dragon's Tail]}

Shaped like smoke, the planet Ketu, stationed in the northeastern direction, ${ }^{81}$ highly frightening with eyes that are round and very extensive may he, having the colour of straw smoke, removing injury from the planets, with terrible fangs and gaping mouth, bring about victory for me! $!^{82}$ (120-121)

\section{[Grahas: Conclusion]}

May these planets, great souls, devoted to the praise of Maheśa, bestow peace on me, full of delight, wishing [me] well at all times! $!^{83}(122)$

\footnotetext{
${ }^{80}$ Rāhu is the son of Kaśyapa and Siṃhikā. $\mathrm{N}_{45}^{c}$ changes saiṃhikeyo to ardhakāyah, a reference to Rāhu's being only a head.

${ }^{81}$ Ketu is the only one of the Navagrahas for which a location in the sky is given.

${ }^{82}$ These two verses are missing in $\mathrm{N}_{77}^{K o}$, which may have important consequences for how we understand the transmission of the text as well as its original time of composition. As discussed earlier (p. 17), it seems plausible that Ketu was added as a ninth Graha at different stages in the transmission of the text. This is suggested not only by the relatively late appearance of Ketu in textual sources in general, but also by the strong variation in readings, which have either two verses or a single verse. The Bhavisyapurāna parallel again has an entirely different reading. $\mathrm{E}^{N}$ adds one more verse after 121, invoking Janman, the name of the first lunar mansion, who is described as bearing a crystal sword (khadgasphațika) in his hand.

${ }^{83} \mathrm{~N}_{58}^{K}$ adds a list of ten Karanas after this, which provides the transition to the following invocation of the Karaṇa Viști. The start of the list is damaged, but it can be easily reconstructed. Traditionally there are held to be 11 Karanas, which each form half of a lunar day (Tithi). Since there are two times 15 Tithis in a lunar month, there are 6o
} 
[The Karana] at whose commencement (mukhe) death is present, she who is named Vișți, very powerful, [the subsequent Viști] with six forms (șanmukhā), creating obstacles, and [the one] bringing victory at the end $(\text { pucche })^{85}$ - the Third, Seventh, Tenth, Fourteenth, Fourth and Eighth, Eleventh and the Night of the Full Moon — on these [Tithis] abounding in obstacles, in the bright and dark fortnight [of the moon's cycle], she is active. May they, having obtained a blessing, bestow peace on me, much longed for! (123-125)

$$
[\text { Tithis }]^{86}
$$

May Amāvāsī (the Night of the New Moon), very auspicious, connected with Pitrrs and Devas, furnished with the splendour of Śiva, bestow peace on me, the supreme and auspicious peace of Śiva, the supreme soul! And the very calm First (Pratipad), and the beautiful Second, and the emi-

Karaṇas. They are divided into two groups: four immovable (sthira) Karaṇas (Śakuni, Catuṣpāda, Nāga and Kiṃstughna), which have a fixed position and appear only once in a cycle, and seven moveable (cara) Karaṇas (Bava, Bālava, Kaulava, Taitila, Gara, Vaṇij, Viștị), which each reappear eight times in a lunar cycle. See Bṛhatsaṃhitā 10o. Only Catuṣpāda is missing in the list of $\mathrm{N}_{58}^{K}$.

${ }^{84}$ Verses $123^{-13} 6$ are missing in $\mathrm{N}_{77}^{K o}$, which may again point to an earlier stage of composition of the text (cf. Ketu above). This is further supported by their absence in the parallel of the Bhavișyapurāna. I follow the common spelling Viști, instead of the otherwise unattested Vṛsți. Vișți is the seventh of the movable Karanas and traditionally regarded as very dangerous. Cf. Bṛhatsaṃhitā 100.4cd: na hi viștikrtạn vidadhāti śubham paraghātavișādișu siddhikaram 'Nothing done during Vișți leads to benefit, [but it] causes success in slaying enemies, poisoning, etc.' It is remarkable that only this Karana should be mentioned here and none of the other ones.

85 The interpretation of the verses addressing Viști is doubtful. I am grateful to Bill Mak for his help in interpreting the text. As he pointed out to me, mukha is used in the sense of 'form' in Jyotișa literature. The verse identifies the eight manifestations of Viști in a lunar month: the first one is associated with death in our text, the following six with obstacles, and the eighth with victory. $\mathrm{P}_{3^{2}}^{T}$ adds an extra two pādas, including a request for śânti, thereby separating the invocation in this verse from the one that follows.

${ }^{86} \mathrm{P}_{3^{2}}^{T}$ and $\mathrm{P}_{7^{2}}^{T}$ have a number of significant variants, which systematically includes the name of the deity presiding over each lunar day: 
nent ${ }^{87}$ Third Tithi, and the very glorious Fourth! The peaceful Fifth and the supreme Sixth Tithi, the auspicious Seventh Tithi, and the very powerful Eighth, this Tithi of the Trident-holder (Śiva), known as the destroyer of evil, the very terrifying Ninth Tithi, which is proclaimed to belong to Durgā! And the splendid Tenth and Eleventh Tithi, and the peaceful Twelfth and the Thirteenth Tithi! The very heroic Fourteenth, the Tithi who is the daughter born from Śankara! And Pūrṇamā (the Night of the Full Moon), of complete self, the constantly blazing Tithi! May the Tithis, constantly auspicious-minded, and in due order, they who are always following the course of the moon during the two halves, constantly bestow peace on me, conforming to Siva's command! (126-132)

$$
[\text { Yogas }]^{88}
$$

Viṣkambha, Prīti, Āyuṣmant, Saubhāgya, Śobhana, Atigaṇda, Sukarman, Dhṛti and Śūla, Gạ̣ḍa, Vṛddhi, Dhruva, Vyāghāta, Harṣaṇa, Vajra, Siddhi, Vyatīpāta, Variyas, Parigha, Śiva, Siddhi, Sādhya, Śubha, Śukla, Brahman, Aindra, Vaidhrtit, these Yogas, very powerful, arisen from the moon and the sun, all devoted to Śiva, following the command of Śiva — may they

\begin{tabular}{|l|l|}
\hline Amāvāsī & Pitṛs and Devas \\
Pratipad & Vahni \\
Second & Arka $\left(\mathrm{P}_{32}^{T}\right)$ \\
Third & Dhanada \\
Fourth & Gajavaktra \\
Fifth & Śī \\
Sixth & Skanda \\
Seventh & Ravi \\
Eighth & Rudra \\
Ninth & Durgāa \\
Tenth & Yama \\
Eleventh & Indra \\
Twelfth & Vișṇu \\
Thirteenth & Madana \\
Fourteenth & Maheśa $\left(\mathrm{P}_{72}^{T}\right)$ \\
Paurṇamāsī & Himāṃśu \\
\hline A comparison
\end{tabular}

A comparison of this table with the list provided by Einoo (2005: 105-106) shows that, despite variation with respect to individual Tithis, there was a general consensus regarding most of the deities presiding over the Tithis.

${ }^{87}$ The form śrimmān is used, where grammatically śrimmatī would be required.

${ }^{88}$ This list of 27 Yogas is standard. 
continuously bestow peace on me and the destruction of sins! ${ }^{89}\left(133^{-}\right.$ 136)

[Nakșatramātṛs: E $]^{90}$

The supreme goddess Kṛttikā, sweet-faced Rohiṇī, eminent, blessed Mṛgaśirā, and highly luminous Ārdrā, Punarvasu, Pușyā, and the very powerful Aśleșā, these Nakṣatramātṛs, adorned with a garland of light, devoted to the praise of Mahādeva, inclined to Mahādeva, they who are stationed in the eastern part - may they always bestow peace on me! (137-139)

\section{[Nakṣatramātṛs: S]}

Maghā, abiding in all qualities, and Pūrvaphālguṇī, the superior Uttaraphālguṇī, Hastā and the excellent Citrā, Svātī, Viśākhā, granter of boons, occupying the southern abode, they worship Deva, the Lord of the three worlds (Tribhuvaneśvara), all the time, these Nakṣatramātṛs, adorned with splendour - may they continuously bestow peace on me, impelled by Śiva. $(140-142)$

\section{[Nakșatramātṛs: W]}

Anurādhā, Jyeșțhā, Mūlā, endowed with wealth and power, the very heroic Pūrvāṣạ̣̄hā, and the splendid Uttarāṣāṭhā, the Nakṣatra named Abhijit, highly luminous Śravanāa, these of kingly form reign, blazing in the west, they worship İsāna all the time, well-disposed — may

\footnotetext{
${ }^{89}$ After this, $\mathrm{N}_{45}^{C}$ adds eight more pādas on the 27 Yogas and also includes a request to Bava, Bālava, Kaulava, Tautila (= Taitila), Gara and Vanija for peace. These are the six other moveable Karaṇas, thus to be added to the already mentioned Vișți (123-125).

90 The designation Nakṣatramātṛs, in reference to the Nakṣatras (lunar mansions), appears not to be attested elsewhere. They are invoked as goddesses $(d e v \bar{v})$. Hazra (1954: 16) uses the order of the Nakșatras mentioned here as an argument for dating the Śivadharmaśāstra to a time before 550 CE. The arrangement from Kṛttikā to Bharaṇī represents the old order, whereas Varāhamihira used the order from Aśvinī to Revatī, which henceforth became the model. On this change of order, see also Yano 2003: 378. The lists in Kirfel 1967: 36 and 138, however, both display the order Kṛttikā to Bharaṇi. Both orders can be found in post-Varāhamihira texts and as such this order does not allow us to date the text before Varāhamihira as Hazra has done.
} 
they bestow peace on me, they who are endowed with great powers! $!^{11}$ $(143-145)$

[Nakșatramātṛs: N]

Dhanișțhā, Śatabhiṣā, ${ }^{92}$ Pūrvabhādrapadā, Uttarabhadrā, Revatī, the very prosperous Aśvinī, and the very heroic Bharaṇi, they who are always stationed in the north, continously devoted to the praise of Śiva, their minds fixed on meditation on Śiva - may they constantly bestow peace on me, at all times, with an auspicious rise. (146-147)

$[\text { Rāśis: } \mathrm{E}]^{93}$

Meșa (Aries), Siṃha (Leo), the king of animals, ${ }^{94}$ and Dhanu (Sagittarius), best of the lights, they shine in the east, intent upon worship of Śiva — may they bestow peace on me, bright, intent on union with Śiva! ${ }^{95}$ (148)

${ }^{91}$ The lengthening of the vowel in vibhütībhih $\left(\mathrm{N}_{12}^{K}\right)$ is metri causa. Pāda $145 \mathrm{~d}$ shows a lot of variation; a reading starting with vibhütim ca may also be considered.

$9^{2}$ The adopted reading is metrically bad, but it receives the best support and is even found in the parallel in the Bhavisyapurāna. The metrically correct readings of $\hat{S}_{67}^{S}$ and $\mathrm{P}_{7^{2}}^{T}$, on the other hand, are quite likely secondary.

93 This section on the zodiac signs (Rāśi) does not follow the regular order, which would rather be: 1) Aries, 2) Taurus, 3) Gemini, 4) Cancer, 5) Leo, 6) Virgo, 7) Libra, 8) Scorpio, 9) Sagittarius, 10) Capricorn, 11) Aquarius, 12) Pisces. Instead we have here the Hellenistic trigon (Sanskrit trikona) system, arranged according to four triangles, groups of three zodiac signs: East $(1,5,9)$, South $(2,6,10)$, West $(3,7,11)$, North $(4,8,12)$. This system was not recognized everywhere, which has led to a number of ambiguities in the transmission of the first two groups in the different manuscript traditions. The trigon system is found in some of the Jātakas, but it is not common elsewhere. See Pingree's note on Yavanajātaka 1.66-67 (Pingree 1978: 223-228). I am grateful to Bill Mak for pointing this out to me.

${ }^{94}$ I adopt mrgādhipah, instead of $v r s ̦ a \overline{d h i p a h, ~ t h e ~ r e a d i n g ~ o f ~ t h e ~ m a j o r i t y ~ o f ~ t h e ~}$ Nepalese manuscripts. Reading vrșādhipah, i.e. Taurus, is problematic because the inclusion of Taurus would interfere with the trigon system underlying this section. It seems likely that the source text originally read mrgädhipah, which was changed to vrșậ̣hipah early in the transmission because a scribe expected the second zodiac sign to be Taurus. Note that mrgādhipah is also the reading of the Bhavisyapurāna parallel.

95 The combined reading of $\mathrm{N}_{77}^{K o}, \mathrm{~N}_{12}^{K}, \hat{\mathrm{S}}_{67}^{S}$ is supported by the Bhavisyapurāna parallel. 
[Rāśis: S]

Vṛṣa (Taurus), ${ }^{96}$ Kanyā (Virgo), the supreme goddess, and Makara (Capricorn), the prosperous, always worship Siva in the southern part, constantly, with highest devotion - may they always bestow peace on me! (149)

\section{[Rāśis: W]}

Mithuna (Gemini), Tulā (Libra) and Kumbha (Aquarius), established in the west - may they, delighting in honouring the feet of Siva, always bestow peace on me! (150)

\section{[Rāśis: N]}

Karkața (Cancer), Vṛścika (Scorpio) and Mīna (Pisces), they who are present in the north, at all times worship Rudra, Lord of the worlds may they, following the command of Siva, constantly bestow peace on me! ${ }^{97}(151)$

${ }^{96}$ The reading adopted in pāda a (vrșaḥ kanyā ca paramā), yielding a na-vipulā, is found only in $\mathrm{N}_{58}^{K}$, but receives some support from $S_{67}^{S}$ and $\mathrm{P}_{32}^{T}$. Moreover, it is also the reading of the parallel in the Bhavisyapurāna. It includes Taurus among the group of three Rāsis located in the south. The reading of the majority of the Nepalese manuscripts (kanyā ca paramā devī), although well supported, is problematic, because only two zodiac signs would be mentioned in the south, which would again interfere with the trigon system. The change may have occurred at the same time that Taurus was introduced in the previous verse. The amount of variation in this part of the text is quite striking. $\mathrm{N}_{45}^{C}, \mathrm{P}_{32}^{T}$ and $\mathrm{P}_{72}^{T}$ have two additional pādas after 149b, mentioning Vṛșa $\left(\mathrm{N}_{45}^{C}\right)$ and Rṣabha $\left(\mathrm{P}_{3^{2}}^{T}, \mathrm{P}_{7^{2}}^{T}\right)$, but in very different wording, suggesting that these two pādas were added independently of each other (see also the additional two pādas in $\mathrm{N}_{58}^{K}$ ).

${ }_{97}$ After this, $\mathrm{N}_{5^{8}}^{K}$ adds six pādas referring to the Tārakagaṇas, nine classes of asterisms. There are some problems in the readings of this passage, but the list corresponds largely with the classification found in Varāhamihira's Ṭikanikayātrā 1.20 (Janma, Sampat, Vipat, Kṣema, Apāya, Śubha, Kașța, Maitra, Atimaitra): tārās tu janmasampadvipatkarā kṣemāpāyaśubhakașțā $\mid$ maitrātimaitrasaṃjñāś caitāḥ saṃjñānurūpaphalāh $\| . S_{67}^{s}$ adds 16 pādas referring to the Saṃkrāntis, the sun's transitions to another house, in accordance with the seven days of the week: Ghorā (Sunday), Dhvānkṣī (Monday), Mahodarī (Tuesday), Mandākinī (Wednesday), Nandanā (Thursday), Miśrikarā (Friday), Rākșasī (Saturday). I have only found these Saṃkrāntis in the Bṛhatpārāśarahorāśāstra: sūryādau sūryasaṃkrāntir ghorā dhvāñkși mahodarī| nandā mandākin̄̄ miśrā rākșasasyeti saptadhā \| (Bṛhatpārāśarahorāśāstra 91.1). The passage may well have been added at a very late moment in the transmission of the text in Kashmir, as is also suggested by the fact that it does not occur in any of the other manuscripts. 


\section{[Seven Sages: Ursa Major]}

The renowned Seven Sages, ending in Dhruva (the polar star), highly luminous - may they, possessed with the favour of Śiva, bestow peace on me, always! (152)

\section{[Sages of Great Vows]}

Kāśyapa, Gālava, Gārgya, the great sage Viśvāmitra, Manu, Dakṣa, Vasișțha, Mārkaṇdạ, Pulaha, Kratu, ${ }^{98}$ Nārada, Bhṛgu, Ātreya, Bharadvāja, the sage Angiras, Vālmīka, Kauśika, Kaṇva, Sākalya, Punarvasu, Śālañkāyana - may these and other sages of great vows, engaged in meditation and praise of Śiva, always bestow peace on me! (153-155)

[Wives, Daughters and Sons of the Sages]

The wives of the sages, very pure, the sages' daughters and sons, ${ }^{99}$ may they, constantly intent upon praise of Śiva, bestow peace on me, always! $(156)$

[Siddhas, Gandharvas, Apsarases, Vidyādharas, Garuḍas]

The Siddhas, who have perfected their asceticism, the flocks of Gandharvas and Apsarases, the Vidyādharas, ${ }^{100}$ great souls, and the Garuḍas, very prosperous - may they, intent upon Maheśvara, worshipping the foot of Maheśvara, quickly bestow success, being intent upon benediction! $(157-158)$

${ }^{98} \mathrm{~N}_{45}^{C}$ inserts more sages, not all of whose names have been transmitted correctly.

${ }^{99}$ I take rșikumärikāh to refer to the sons as well as the daughters of the sages, in accordance with the format followed in the Daitya section below. The variant reading rșikanyākumārikāh may also be considered.

${ }^{100}$ The reading of $\mathrm{N}_{77}^{K o}, \mathrm{~N}_{82}^{K}$ and $\mathrm{B}_{99}^{C}$ looks defective in $157 \mathrm{bc}$ and may have arisen due to an early eye-skip. With some hesitation I follow the reading suggested by most of the other manuscripts. 
[Daityas: 1]

Namuci, the king of the Daitya lords, the very powerful Śankukarṇa, ${ }^{101}$ the Daitya called Mahānāda, of great heroism — may they, constantly intent upon the worship of god Hātakeśvara, ${ }^{102}$ very prosperous, quickly bestow power and heroism on me! (159-160)

[Daityas: 2]

Mahājambha, Hayagrīva, Prahlāda, Anuhlādaka, Tāraka, the Daitya Agnimukha, Kālanemi, Mahotkața - may these Daityas, great souls, devoted to the reality of Śiva, grant prosperity, power and heroism, resulting in joy! (161-162)

[Daityas: 3]

Virocana, Hiranyākșa, Suparva, and Sulomaka, Mucukunda, Sukunda, and the Daitya Revataka, they constantly worship Siva, instantly, with supreme intent - may they, constantly benevolent, grant prosperity to me, always! (163-164)

[Wives, Daughters and Sons of the Daityas]

The illustrious wives of the Daityas, the splendid daughters of the Daityas and the sons of the Daityas - may they always bestow peace on me! (165)

${ }^{101} \mathrm{P}_{72}^{T}$ adds three more Daityas: Jambha, Nikumbha and Śakața.

${ }^{102}$ Hāțakeśvara: Śiva as lord of Pātāla. Many of the Daityas mentioned here feature in Purāṇic descriptions of the Pātāla. See, for example, Kirfel 1967: 145, based on the descriptions in the Vāyu-and Brahmāṇdapurāna: in the first Tala are e.g. the abodes of Namuci, Mahānāda and Śankukarna, in the second those of Mahājambha, Hayagrīva and others, in the third those of Prahlāda, Anuhlāda, Tāraka and others, etc. Although not all of the Daityas mentioned in the Purānic descriptions are listed here, the order of the Daityas listed corresponds with those of the Daityas dwelling in ever lower Talas. 


\title{
[Eight Nāgarājas] ${ }^{103}$
}

\author{
[1. Ananta]
}

With a red body, elongated eyes that are red at the edges, swelling with pride with his great hood, marked by a conch and a lotus ${ }^{104}$ may Ananta, king of the Nāga lords, delighting in the praise of Siva's feet, destroy the poison of great evil and quickly bestow peace on me! $(166-167)$

\section{[2. Vāsuki]}

With a very white body, with a crown of very white lotuses, swelling with pride with a handsome hood, adorned with a charming necklace — may Vāsuki, king of the Nāga lords, the great one, intent upon the worship of Rudra, destroy the poison of great evil and quickly bestow peace on me! $(168-169)$

${ }^{103}$ On the Nāgarājas, see Vogel 1926: 189-219. As for the colours associated with the Nāgarājas, there are different traditions (Wayman 1987: 68-69). Rao 1914-16, II: 556557, referring to the Mayaśilpa, gives the following details for the seven serpent lords: Vāsuki (pearlwhite); Takșaka (glistening red, with a svastika on the hood); Karkoțaka (black, with three white stripes on the hood); Padma (rosy, with a white streak and adorned with coral ornaments); Mahāpadma (white, with the mark of the triśüla on the hood); Kulika (red, with the mark of the crescent moon on the head). Many of these features are shared in remarkable detail with the descriptions in the present passage. The Mayaśilpa passage quoted by Rao in Appendix B, p. 274, runs as follows:
śvetadehaś ca kartavyas sphuranmauktikasannibhaḥ|
raktāingas svastikopetas sutejās takșako mahān \|
krșnahạ kārkoțakaḥ kaṇțhe śuklarekhātrayānvitạ̣|
raktapadmanibhạ̣ padmạ̣ śiraś śuklas savidrumạ̣ \|
śan்khavarṇo mahāpadmo mastake krșnaśūladhṛk|
hemābhaś śañkhapālas syāt sitarekhādharo gale \|
kuliko raktadehas tu candrārdhakrtamastakah |
dvijihvā bāhuvat saptaphañāmaṇisamanvitāh $\|$
akșasūtradharās sarve kuṇdikāpucchasamyyutāḥ|
ekabhogās tribhogā vā hy etajjātās sutādayaḥ\|

${ }^{104}$ The attributes of conch and lotus connect Ananta with Viṣnu. 


\section{[3. Takșaka ${ }^{105}$}

With a very yellow body, rich in quivering coils, and with a very luminous splendour, marked by the Svastika — may Takșaka, the illustrious Nāga lord, accompanied by a crore of Nāgas, bestow peace on me, destroying the poison of all crimes! (170-171)

\section{[4. Karkoțaka]}

With a very black colour, an expanding hood over his head, provided with three lines on his neck, ${ }^{106}$ furnished with terrible fangs as weapons may the great Nāga Karkoțaka, possessed of poisonous pride and power, destroy the pain of poison, weapon and fire, and bestow peace on me! (172-173)

\section{[5. Padma]}

With a lotus-coloured body, his elongated eyes like handsome lotus [petals], illuminated with five spots - may the great Nāga called Padma, delighting in the praise of Hara's feet, bestow peace on me, destroying the poison of great evil! (174-175)

\section{[6. Mahāpadma]}

And with a body like a white lotus, of immeasurable splendour, always adorned on his head with [the marks of] a brilliant conch, trident and lotus - may the great Nāga Mahāpadma, constantly bowing to Paśupati, destroy the terrible poison and quickly bestow peace on me! (176-177)

$$
\text { [7. Śan̉khapāla] }
$$

With a dark body-mass, his eyes like beautiful lotuses, intoxicated with poisonous pride and power, with a single line on his neck — may Śankkhapāla, bright with lustre, worshipping the lotus-feet of Śiva, destroy great evil, the great poison, and bestow peace on me! (178-179)

\footnotetext{
${ }^{105}$ For an identified Takșaka sculpture, see Sircar (1971: 138-140), who refers to a Nāga sculpture in the State Museum Lucknow, whose pedestal is inscribed in eighth-century Siddhamātṛkā script with the words śrìtakhakanāga, i.e. śrìtakșakanāga.

${ }^{106}$ Cf. Niśvāsamukha 3.168, where Karkotaka is called Trirekhin.
} 


\section{[8. Kulika]}

With a very terrifying body, his head furnished with the sickle of the moon, swelling with pride with a shining hood, marked with an auspicious mark - may Kulika, the best of the Nāga kings, always intent upon Hara, remove the terrible poison and bestow peace on me! (180-181)

\section{[Other Nāgas]}

The Nāgas in the sky, the Nāgas abiding in heaven, the Nāgas abiding on earth, at mountains, in caves and forts, the Nāgas present in the nether region - may all of them, assembled here, dedicated to the praise of Rudra's feet, bestow peace on me! (182-183)

\section{[Wives, Daughters and Sons of Nāgas]}

The Nāgas' wives, the Nāgas' daughters and the Nāgas' sons — may they, devoted to Śiva, benevolent, always bestow peace on me! (184)

\section{[Śrutiphala of Nāga section]}

Snakes do not harm the one who will recite or hear this totality of Nāgas, nor does poison ever reach him. $(185)^{107}$

\section{[Rivers: 1]}

The holy great goddess Gangā, Yamunā, the river Narmadā, Gomatī, Kāverī, Varuṇā, ${ }^{108}$ as well as Devikā; ${ }^{109}$ [these] rivers always worship Deva, the lord of all creatures, the supreme lord, Maheśvara, devoted to the reality of Śiva - may they constantly bestow peace on me and destroy evil; let them quickly grant success, being free from all obstacles! (188)

\footnotetext{
${ }^{107}$ This is the only case in which the text inserts a statement about the śrutiphala. $\mathrm{P}_{3^{2}}^{T}$ and $\mathrm{P}_{72}^{T}$ add four more pādas about the results to be obtained from the recitation.

${ }^{108}$ The Varunā is a tributary of the Ganges, joining the great river at Vārāṇasī (SP IIA, 222).

109 Hazra (1954: 16-17) takes the mention of Devikā here and Candrabhāgā below as evidence for a northwestern origin of the text. $\mathrm{P}_{32}^{T}$ adds four more rivers after this: Kauśikā, Sarasvatī, Tāmraparṇī and Sarayū.
} 
[Rivers: 2]

The very holy Candrabhāgā, the splendid river Godāvarī, Sarayū, the superior Gaṇạakī, Kauśikī and Sarasvatī - may these highly fortunate rivers, pleased, delighting in praising Siva's feet, bestow peace on me, single-minded in their meditation on Śiva! (190)

[Rivers: 3]

The river called Nairañjanā, ${ }^{110}$ and the great river Śṇa, the supreme Mandākinī, and the splendid Samnihitā ${ }^{111}$ — may these and many other rivers, flowing on earth, in heaven and in the sky, intent upon Rudra's praise, bestow peace on me! $(192)^{112}$

[Yakșas]

[1. Mahāvaiśravaṇa $]^{113}$

The god Mahāvaiśravana, the prosperous lord of the Yakșas, with a retinue of crores of Yakșas, joined by a host of Yakșas, endowed with great majesty, delighting in the praise of Hara's feet, single-minded in meditation on Hara, best of those who bow down to Hara's feet ${ }^{14}$ - may he, delighted, bestow peace on me, his elongated eyes like lotus-petals! (193-194)

110 The presence of the Nairañjanā in this list is noteworthy. The name of this river, identified with the present-day Phalgu, flowing near Bodhgayā (Dey 1971: 135), features in Buddhist sources (e.g. Buddhacarita 12.91a), but appears not to be attested elsewhere outside of Buddhist literature.

${ }^{111}$ This may be the Saṃnihitī or Samnihityā, a tīrtha in Kurukṣetra (MBh 3.81.167169). See SP IIA: 232, and Kane IV: $801 . \mathrm{N}_{58}^{K}$ and $\hat{S}_{67}^{S}$ add a few more rivers in the northwest with some variations in naming and spelling.

${ }^{112} \mathrm{~N}_{58}^{K}$ adds eight more pādas, invoking the earth with her continents and all tìrthas and lakes on earth, inhabited by Śrīkanthha. The last four pādas of this addition are shared with $\hat{S}_{67}^{S}, \mathrm{P}_{32}^{T}$ and $\mathrm{P}_{72}^{T}$.

${ }^{113}$ Vaiśravana is another name for Kubera, who is mentioned in his function as Dikpāla above (96-98). Here he appears in a different identity, as the lord of the Yakșas.

${ }^{114} \mathrm{~N}_{58}^{K}$ adds two pādas on worship by the Yakșiṇīs and Yakșas' daughters for pleasure and liberation. 


\section{[2. Manibhadra ${ }^{115}$}

The great Yakṣa Manibhadra, decorated with gems and jewels, shines with a captivating necklace attached to his neck, his body surrounded by Yakșiṇis and Yakșa daughters — may he, fully engaged in the praise of Rudra, bestow peace on me! (195-196)

\section{[3. Suviroma $]^{116}$}

And the Yakșa lord Suviroma, decorated with gems and earrings, shines with a beautiful golden turban on his forehead, surrounded by many Yakșas, his body venerated by Yakșas - may he, devoted and intent upon worshipping Śiva, bestow peace on me! (197-198)

\section{[4. Pāñcika] $]^{117}$}

The Yakșa lord named Pāñcika, blazing with a necklace and armlets, shines with a brilliant tiara and two bracelets, joined by hosts of Yakșas, accompanied by crores of Yakșas - may the illustrious one, intent upon praising Hara, bestow peace on me! (199-200)

${ }^{115}$ Maṇibhadra is one of the better known Yakșas, second only to Kubera/Vaiśravana. See Misra 1981: 81-85. Stadtner 2002 discusses a Gupta sculpture of Manibhadra, dated to 431 CE. For an earlier inscribed Manibhadra sculpture found at Pawaya, now at the Gwalior Archaeological Museum, see Huntington: oo138o6. A recently published copperplate inscription of Vainyagupta attests to the worship of Manibhadra in eastern India in the sixth century (Furui 2016). See also Quintanilla 2007: 27-30, for epigraphic and other references to Manibhadra.

${ }^{116}$ The name Suviroma, while different in meaning, recalls the Yakșa Suciloma ('needle-haired'), who, according to Pāli sources, converted to Buddhism (Misra 1981: 117-118). Note the reference to the turban, which, like that of other Yakșas, is a prominent feature of his sculpture at Bharhut: AIIS 34309. The Bharhut sculpture bears the label suchilomo yakho (CII II/II: 79 [B9]). The variant reading suviro näma in a number of manuscripts looks secondary.

${ }^{117}$ Pāñcika is the consort of Hārītī and is well represented in Gandhāran and postGandhāran art. See Misra 1981: 73-8o. 


\section{[5. Vibhāṇḍaka $]^{118}$}

The illustrious Yakṣa Vibhāṇdaka, decorated with various jewels, constantly shines with a beautiful supreme earring on his ear, the lord of Yakșas, master of Yakșas, staunch general of the Yakșas - may the illustrious one, honouring the feet of Hara, bestow peace on me! (2O1-2O2)

\section{[6. Dhṛtarāșțra ${ }^{119}$}

The very lustrous Yakșa Dhṛtarāṣtra, powerful lord of Yakṣas, covered with a divine turban and garment, decorated with jewels and gold may he, devoted to Śiva, meditating on Śiva, intent upon worshipping Śiva, endowed with the favour of Śiva, bestow peace on me! (203-204)

\section{[7. Pūrṇabhadra $]^{120}$}

The great Yakșa Pūrṇabhadra, decorated with all kinds of adornments, shines incredibly with a golden turban bright with jewels - may he, furnished with an entourage of a thousand crores of Yakșas, ${ }^{121}$ engaged in praising Rudra, bestow peace on me! (205-206)

${ }^{118}$ Vibhānd diaka was a sage of the line of Kaśyapa. When he chanced on the Apsaras Urvaśi he shed his seed. The seed was swallowed by an antelope, who gave birth to Rṣyaśrnnga. The birth story is told in MBh 3.110. Could this be related to the Yakșa Virūḍhaka, who is the Dikpāla guarding the southern direction in Buddhist sources (see note below)?

${ }^{119}$ Dhṛtarāștra is another well-known character from the Mahābhārata. However, in Buddhist mythology Dhṛtarāșțra is one of the four great kings (caturmahārājika), guardians of the directions: Dhṛtarāșțra/Dhatarațța (E), king of the Gandharvas; Virūḍhaka/Virūḷha (S), king of the Kumbhāṇ̣as; Virūpākṣa/Virūpakkha (W), king of the Nāgas; Vaiśravaṇa/Vessavaṇa (N), king of the Yakșas. See Kirfel 1967: 195-196; Haldar 1977: 80-81; Wessels-Mevissen 2001: 18-19. For sculptures of two of them, with labels referring to them as Yakșas (kupiro yakho [B1], virudako yakho [B4]), on the pillars of the great stūpa at Bharhut, see Cunningham 1879: 19-20.

${ }^{120}$ Pūrnabhadra is a prominent Yakșa. See Misra 1981: 85-87.

${ }^{121}$ After this, all manuscripts except $\mathrm{B}_{99}^{C}$ and $\mathrm{N}_{82}^{K}$ add two more pādas on Pūrṇabhadra's devotion to Rudra. While this may suggest a case of eye-skip on the part of $\mathrm{B}_{99}^{C}$ and $\mathrm{N}_{82}^{K}$ (rudra- $\rightarrow$ rudra-), it is quite conceivable that the two pādas were added accidentally in an early archetype. This is suggested by the wide distribution of variants in the second pāda of the addition. The scenario may have been as follows: somebody accidentally started a pāda rudraprañāmaparamo (an easy slip of the pen), which was subsequently completed by different scribes with an additional pāda in different ways. The content of these two pādas is redundant. 


\section{[8. Virūpākșa ${ }^{122}$}

And the best of Yakṣas, Virūpākṣa, who has a white garment, very luminous, adorned with beautiful golden garlands furnished with tinkling bells, ${ }^{123}$ at all times solely intent upon granting boons - may he, intent upon worshipping Rudra, devoted, bestow peace on me! (207-208)

\section{[Other Yakșas]}

The Yakșas in the sky, the Yakșas dwelling in heaven, the Yakșas dwelling on earth, on mountains, in caves and forts, the Yakșas in the sky, those dwelling in the bottom of the nether region, the Yakșas with various kinds of weapons, wearing various dresses, devoted to Śiva, good-minded, eager for worship of Śiva - may they, delighted, bestow peace on me, peaceful, intent upon peace! (209-211)

[Wives, Sons and Daughters of the Yakșas]

The Yakșas' wives, of various appearances, and the Yakșas' sons, the illustrious Yakșas' daughters, delighting in the worship and praise of Śiva may they quickly grant peace, blessing, safety, power, the highest happiness, constantly, all together! (212-213)

${ }^{122}$ Virūpākșa is one of the four guardians of the directions in Buddhist literature. See the note on Dhṛtarāsțra above.

${ }^{123}$ I follow the readings of the majority of the manuscripts, which is grammatically irregular but quite probably original. The variant reading in $\mathrm{N}_{82}^{K}, \mathrm{~B}_{99}^{C}$ and $\mathrm{E}^{N}$ has 'endowed and decorated with bells that have a beautiful golden colour' instead. 
$[\text { Mountains }]^{124}$

And may all mountains always, the very prosperous mountains, devoted to Siva all the time, all the time bestow peace on me! (214)

$$
[\text { Oceans }]^{125}
$$

May all the oceans everywhere, the oceans present everywhere, always intent upon worshipping Rudra, bestow peace on me! (215)

$$
\text { [Rākṣasas] }]^{126}
$$

All the Rākṣasas everywhere, the Rākșasas of terrifying form, the very heroic Rākșasas, the very powerful Rākṣasas, the Rākṣasas present on earth, the Rākșasas in the sky, those in the nether region and on the surface of the earth, constantly intent upon Rudra ${ }^{127}$ — may they always

${ }^{124}$ There are many different additions related to this section. Before this, $\mathrm{N}_{45}^{C}$ adds 14 pādas, referring to the islands Jambudvīpa, Saākadvīpa, Kuśadvīpa, Krauñca, Saālmalika, Plakșadvīpa, Gomedha and Puṣkara, and the mountains Meru, Mandara, Kailāsa, Malaya, Gandhamādana, Śrīparvata, Hemakūța and Mālyavat. A later hand in $\mathrm{B}_{99}^{C}$ has added 22 pādas with many mistakes, which are of similar content but different in wording. The passage first lists the mountains Meru, Mandara, Kailāsa, Malaya, Gandhamādana, Śrīparvata, Mahendra and Himakūța, followed by the islands Jambudvīpa, Plakṣadvīpa, Kuśadvīpa, Krauñcadvīpa, Śākadvīpa, Gomedhadvīpa and Puṣkaradvīpa, and the seven oceans Kșāroda, Kṣīroda, Dadhna, Ghṛtoda, Suroda, Dahvadambha(?) and Ikșusvāda. $\mathrm{N}_{58}^{K}$ adds 18 pādas, listing roughly the same islands, oceans and mountains, but in slightly different terms. $\mathrm{E}^{N}$ adds four pādas, which only list the mountains in the same form as we find them in the additional passage in $\mathrm{B}_{99}^{c}$, while it has the names of the continents and the seven oceans after 214. $S_{67}^{S}$ presents yet a different case, listing the islands as Jambudvīpa, Śākalya, Kuśa, Krauñca, Śālmali, Gomedha and Puṣkara, the oceans as Kṣārodadhi, Kṣīrodadhi, Dadhna, Ghṛtodaka, Ikṣupūrṇa, Suroda and Svāduda, and the mountains as Meru, Mandara, Kailāsa, Malaya, Gandhamādana, Mahendra, Śrīgiri and Hemakūṭa. It looks like different transmitters were responsible for the additions of these passages, all dealing with similar content but with differences in wording and phrasing. For clarity's sake I have silently normalized the various names, which show variations in the different manuscripts.

${ }^{125}$ Before this, $\mathrm{E}^{N}$ adds four pādas, referring to the islands (see note above) and the seven oceans Kṣāroda, Kṣiroda, Dadhna, Ghṛtoda, Suroda, Svāduka and Ikṣusvāda.

${ }^{126}$ At this point in the text, the structure of the invocation changes, with invocations dedicated to deities that show a close connection to Śiva's Bhairava form. Cf. also the comment in the Sivadharmavivarana.

${ }^{127}$ After this, $\mathrm{N}_{77}^{K o}, \mathrm{E}^{N}, \mathrm{P}_{32}^{T}$ and $\mathrm{P}_{72}^{T}$ share two additional pādas: 'may they always bestow peace on me, being constantly intent upon Siva'. This addition is superfluous. 
bestow peace on me, through the splendour of that god who has a terrifying form and who is covered with the ashes of the dead! (216-218)

\section{[Yoginīs and Ḍākiṇīs]}

The very powerful Yoginīs, with a dress that is constantly blazing, beautiful, of various appearances, and the very prosperous Ḍākin̄īis ${ }^{128}$ - may they, delighting in bowing to Rudra, delighting in the worship and praise of Rudra, their minds dedicated only to Rudra, bestow peace on me! The Dâkiṇīs in the sky, those abiding in heaven, the Ḍākiṇis in the nether region, those present on mountains and forts ${ }^{129}$ - may they always bestow peace on me, through the splendour of that god who has a third eye, a trident and shining ashes! (219-222)

\section{[Bhūtas]}

All the spirits (Bhūtas) of great form, all the spirits of great splendour, all the spirits present, all the auspicious spirits, swift as thought, the spirits in the sky, the spirits abiding in heaven, the spirits in the nether region and on the surface of the earth, granting riches - may they always bestow peace on me, through the splendour of that god who has a spotless skull-staff, a trident and shining ashes! $!^{130}(223-225)$

\section{[Pretas]}

All the ghosts (Pretas), the groups of ghosts, the ghosts facing all directions, the very brilliant ghosts, the ghosts feeding on blood, the ghosts in the sky, the ghosts dwelling in heaven, the ghosts in the nether region and on the surface of the earth, the ghosts taking form at will — may they always bestow peace on me, through the splendour of that god who has his abode on the cremation ground, whose vehicle is a bull! (226-228)

${ }^{128}$ Dākinīs are attested for the first time in the Gangdhār stone inscription of Viśvavarman, dated Mālava-Vikrama era 48o (ca. 423-424 CE), referring to a temple dedicated to the Mothers (mātrnāịn veśman) that is filled with Dākiṇis (ḍākinisamprakìnam). For the text of the inscription, see Sircar 1965: 399-405. The same inscription mentions the establishment of a Viṣnu temple and a well, all by Mayūrākṣa, the minister of Viśvavarman.

${ }^{129}$ Or alternatively: 'on hillforts'.

${ }^{130}$ Instead of bhasma bhāsuram quite a few manuscripts have karapallave '[a trident] in his fingers'. 


\section{[Piśācas]}

The very heroic Piśācas, prosperous, very powerful, all bearing various forms, all most excellent, the Piśācas in the sky, the Piśācas in heaven, the Piśācas on earth and in the nether region, of many forms, swift as thought - may they always bestow peace on me, through the splendour of that god who has the digit of the moon on his head and who bears the Gañgā in his twisted hair! (229-231)

\section{[Grahas]}

All the epilepsy-seizers, and all the fever-seizers, the foetus-seizers, and those seizers of various diseases, the seizers in the sky, the best of seizers in heaven, the seizers on earth and in the nether region, the seizers in all directions - may they always bestow peace on me, through the splendour of that god who has a dark-blue neck and who has a snake for an ornament! (232-234)

\section{[All Deities]}

May all these deities and others, who are following the command of Śiva, bestow peace on earth to the devotees of Siva! ${ }^{13}$ (235)

$$
\text { [Jaya] }
$$

Victory to [You] residing in your own yoga, victory to [You] of pure consiousness, victory to the Single Hero of Boons, victory to the Lord, homage be to You!

Victory to the Supreme God, victory to the Maker of Happiness, victory to [You] with a manifest body, victory to [You] who are the object of the muttering of prayers, homage to You!

${ }^{13^{1}}$ After this, $\mathrm{P}_{3^{2}}^{T}$ and $\mathrm{P}_{72}^{T}$ add a transitional verse introducing the following Stotra. $\hat{S}_{67}^{S}$ has two different verses, the first of which starts with four pādas quoted by Jayaratha in his commentary on Tantrāloka 1.159: ittham nānāvidhair rūpaih sthāvaraih jañgamair api $\mid$ krị̂daya prasrto nityam eka eva śivah prabhụ̣ || 'Thus Śiva, the Lord, the one and only, issues forth through play, with manifold forms, both moving and unmoving. The verse is connected in $S_{67}^{S}$ with the refrain 'may he always bestow peace on me, long life and happiness!' The second verse states that one who desires success, enjoyment and release should hear and recite it. 
Victory to the Receptacle of Fortune, victory to the Bestower of Splendour, victory to [You] of pure speech, to the Unconquered, homage, homage! $!^{12}$

Victory to [You] with the trident in his hand, victory to [You] bearing the skull-staff, victory to [You] who have conquered the world, victory to Form, homage to You!

Victory to [You] half of whose body is your beloved, victory to [You] who wear the digit of the moon, victory to the Supergod of Gods, victory to Rudra, homage to You!

Victory to the Lord of the Three Worlds, victory to [You] of celebrated fame, victory to the Entire Support, victory to the Creator, homage, homage! ${ }^{133}$

Victory to the Bestower of Liberation, to the Effecter of Creation and Destruction, to [You] worshipped by Brahmā, Viṣnu and Indra!

Śiva, homage be to You, the Gentle! $(236-242)^{134}$

\section{[Śrutiphala]}

He who recites or hears this chapter on appeasement will rejoice in Sivaloka, having quickly shaken off evils.

One aiming for a girl obtains a girl, one aiming for victory obtains victory, one aiming for wealth obtains wealth, one aiming for sons obtains many sons, one aiming for knowledge obtains knowledge, one aiming for union obtains union.

Whatever desires one may aim for, a man obtains all of that here quickly by listening, and he becomes dear to the gods.

A man who should enter battle after hearing this auspicious chapter ${ }^{135}$ will conquer his enemies in battle and be honoured with fortunes.

\footnotetext{
${ }^{132} \mathrm{~N}_{45}^{C}$ and $\hat{S}_{67}^{S}$ insert four pādas, invoking Śiva as the one of pure knowledge, the one who contemplates all, the one who is completely pure and who has eight embodiments (aștamūrti).

${ }^{133} \hat{\mathrm{S}}_{67}^{S}, \mathrm{P}_{32}^{T}$ and $\mathrm{P}_{72}^{T}$ insert four pādas (with variants) invoking Śiva as the one who has a nonmaterial $\left(\hat{S}_{67}^{S} ;\right.$ em. nișkala-) or spotless $\left(\mathrm{P}_{7^{2}}^{T}\right)$ body, who accomplishes all goals, destroyer of Kāma.

${ }^{134} \mathrm{P}_{3^{2}}^{T}$ adds two more pādas invoking Śiva as being free from birth and all-pervading.

${ }^{135}$ Variant in $\mathrm{N}_{82}^{K}$ : 'A man who should enter battle, while reciting the chapter on appeasement ...'
} 
He will enjoy [his kingdom] for an endlessly long time, with his orders not rejected. He will not be overpowered by diseases and thrive with sons and grandsons.

Diseases arising from wind and bile do not bind the one for whose sake this auspicious recitation is recited.

He will not encounter death at an inappropriate time, and he will not be bitten by snakes. Poison will not enter his body and there will be no paralysis, blindness or dumbness [for him].

For him there will be no danger from misfortunes, there will be no fear of calamity, he will never be polluted by vices created by black magic.

The merit of all Tìrthas, in particular of such as the river Gangā, that merit, multiplied by crores, one obtains in this world by hearing it.

By hearing it, one will obtain the fruit of ten Rājasūya sacrifices and of a hundred Agnișțomas, multiplied by crores and crores.

He cannot be slain by all the gods and other beings in particular; he will live the full hundred years free from all diseases.

A cow-killer and an ungrateful person, a brahmin-slayer and one who violates his teacher's bed, one who murders someone who comes for protection and one who betrays the trust of friends, one engaging in wicked evil, a mother's killer and a father's killer - by hearing it intently, such a person will be released from all sins.

This auspicious chapter on appeasement should not be given to just anyone. It should be given to the devotee of Śiva. It was told earlier by Siva. ${ }^{136}$ $\left(243^{-256)}\right.$

Thus in the Śivadharmaśāstra, the Sixth, the Chapter on Appeasement.

${ }^{136}$ The first and the last verse of the Śantyadhyāya both specify that it was Rudra/Śiva who first taught this invocation in the past. $\mathrm{P}_{3^{2}}^{T}$ and $\mathrm{P}_{72}^{T}$ add four more pādas about the results of daily recitation, while $S_{67}^{S}$ only has the last two of them. 